\title{
PERANCANGAN APLIKASI INVENTORY BARANG PADA PT KARTIKA GRAHA INDONESIA BERBASIS JAVA NETBEANS
}

\author{
Arini Dwi Pratiwi \\ Program Studi Informatika, Fakultas Teknik dan Ilmu Komputer, Universitas Indraprasta PGRI \\ Jalan Raya Tengah No 80, Kelurahan Gedong, Pasar Rebo, Jakarta Timur \\ arinydwipratiwi@gmail.com
}

\begin{abstract}
Abstrak
Sistem inventory adalah sebuah hal yang penting dalam suatu perusahaan, maka harus diatur secara efektif dan efisien. Tujuan penelitian ini adalah menganalisa sistem yang sedang berjalan pada PT Kartika Graha Indonesia. Metode yang digunakan adalah grounded research yaitu metode penelitian berdasarkan pada fakta dan menggunakan analisis perbandingan bertujuan untuk mengadakan generalisasi empiris, menetapkan konsepkonsep, membuktikan teori, dan mengembangkan teori di mana pengumpulan data dan analisis data berjalan pada waktu yang bersamaan. Metode analisis dilakukan dengan observasi langsung di perusahaan, dokumentasi dengan mempelajari dokumen-dokumen yang ada, riset terhadap masalah, dan wawancara terhadap pihak terkait di perusahaan. Metode kepustakaan dilakukan dengan mencari informasi tambahan dari berbagai buku. Peneliti mendapatkan hasil penelitian bahwa sistem inventory barang bermanfaat bagi perusahaan. Adapun manfaat bagi perusahaan dalam kebutuhan persediaan barang yang ada. Kesimpulan dari penelitian ini adalah dengan diterapkannya aplikasi sistem inventory barang pada perusahaan, menjadi lebih baik dan lebih terstruktur.
\end{abstract}

Kata Kunci: Aplikasi, Inventory, Java Netbeans

\begin{abstract}
Inventory system is an important thing in a company, it must be managed effectively and efficiently. The purpose of this research is to analyze the current system in PT Kartika Graha Indonesia. The method used is grounded research i.e. research methods based on facts and use comparative analysis aims to conduct empirical generalizations, define concepts, prove theories, and develop theories in which data collection and data analysis run at the same time. The analysis method is done with the direct observation of the company, documentation by studying the existing documents, research into problems, and interviews to related parties in the company. The library method is done by looking for additional information from various books. Researchers get the research results that the goods inventory system is beneficial for the company. The benefits of the company in the supply needs of existing goods. The conclusion of the research is that the application of inventory goods system in the company, become better and more structured.
\end{abstract}

Keywords: Application, Inventory, Java Netbeans

\section{PENDAHULUAN}

Pada era globalisasi, pengetahuan mengenai teknologi informasi berkembang sangat pesat. Penggunaan alat bantu komputer sebagai salah satu sarana penunjang dalam meningkatkan kinerja dan memberikan kemudahan pada pekerjaan yang membutuhkan kecepatan dan ketetapan untuk mengolah data dalam jumlah besar, salah satunya adalah untuk mengontrol persediaan barang (inventory). Inventory dapat diartikan sebagai suatu proses data tentang keluar masuk barang dalam suatu bidang usaha (Miftahul, 2010). Selain itu, informasi yang akurat mengenai persediaan barang (inventory) di gudang, baik berupa pembelian maupun hasil penjualan barang dan jasa, juga merupakan hal yang sangat penting dalam perusahaan, terutama untuk memenuhi permintaan proyek (lapangan). PT Kartika Graha Indonesia adalah perusahaan yang bergerak dalam bidang kontraktor. Berdasarkan hasil informasi yang peneliti dapatkan, dalam pendataan seluruh barang yang ada di perusahaan sudah menggunakan terkomputerisasi, tetapi hanya dengan menggunakan form yang dibuat di Microsoft Excel. Penggunaan form tersebut memiliki kelemahan, misalnya arsip-arsip yang telah disimpan akan membutuhkan waktu yang cukup lama proses pencarian. Dengan sistem yang dimiliki oleh perusahaan saat ini, tidak mustahil terdapat kesalahan informasi mengenai data barang, 
yang disebabkan oleh kesalahan dalam peng-input-an data. Dengan adanya masalah tersebut maka dirasa perlu untuk membuat aplikasi persediaan barang (inventory) agar dapat diakses oleh PT Kartika Graha Indonesia.

Tujuan dari penelitian ini antara lain, mempercepat proses pencarian barang yang dibutuhkan secara mudah dan efisien, mempermudah pembuatan laporan barang dan melihat stok barang yang ada, untuk mengetahui sistem pengolahan data inventory barang yang sedang berjalan pada PT Kartika Graha Indonesia yang akan dilakukan dengan sistem aplikasi yang baru, mengetahui kelebihan dan kekurangan dari sistem yang sedang berjalan pada PT Kartika Graha Indonesia dalam perancangan sistem inventory. Pengertian sistem adalah sekelompok unsur yang erat hubungannya dengan yang lain, yang berfungsi bersama-sama untuk mencapai tujuan tertentu. Sistem dapat berupa abstrak atau fisik. Sistem yang abstrak adalah susunan gagasan-gagasan atau konsepsi yang teratur yang saling bergantungan, sedangkan sistem yang bersifat fisik adalah rangkaian unsur yang bekerja sama untuk mencapai suatu tujuan (Sutabri, 2012). Hasil penelitian ini berupa aplikasi sistem inventory yang dapat memudahkan perusahaan dalam mengelola persediaan barang menjadi lebih baik dan lebih terstruktur.

\section{PENELITIAN RELEVAN}

Peneltian oleh (Hasanudin, 2018) dengan judul "Rancang Dan Bangun Sistem Informasi Inventori Barang Berbasis Web (Studi Kasus PT Nusantara Sejahtera Raya). Penelitian tersebut bertujuan untuk membuat sistem informasi inventori barang, yang dapat mengelola barang masuk dan keluar, stok barang, transaksi pemesanan barang dengan menggunakan Data Flow Diagram (DFD) untuk pemodelan terstruktur. Hasil penelitian tersebut adalah aplikasi berbasis web yang dapat mengelola data barang masuk dan keluar, data stok barang, pemesanan barang dalam satu aplikasi berbasis web. Penelitian oleh (Syarif \& Mustagfirin, 2018) Penelitian tersebut bertujuan untuk merancang sistem Inventory barang yang sesuai dengan permasalahan pada kegiatan persediaan barang pada Apotek Sultan supaya mempermudah dalam mengelola dan mendata barang masuk dan keluar. Pengumpulan data dilakukan dengan wawancara langsung dan studi pustaka. Sistem informasi yang telah dihasilkan dapat mengelola data barang masuk dan keluar, stok barang dan laporan transaksi. Hasil dari penelitian ini ialah sistem yang sudah terkomputerisasi dapat mempermudah dalam proses pendataan barang masuk dan keluar sehingga lebih mudah dalam pencarian data yang diperlukan, dan dengan adanya laporan yang terkomputerisasi dapat memberikan informasi yang cepat, tepat dan akurat.

\section{METODE PENELITIAN}

Metode penelitian yang digunakan adalah pedoman atau prosedur serta teknik dalam perencanaan penelitian yang berguna sebagai panduan untuk membangun strategi yang menghasian model atau blue print penelitian. Metode penelitian adalah cara ilmiah untuk mendapatkan data dengan tujuan dan kegunaan tertentu (Sugiyono, 2014). Metode penelitian yang digunakan oleh peneliti adalah metode grounded (grounded research), yaitu metode penelitian berdasarkan pada fakta dan menggunakan analisis perbandingan bertujuan untuk mengadakan generalisasi empiris, menetapkan konsep-konsep, membuktikan teori, dan mengembangkan teori di mana pengumpulan data dan analisis data berjalan pada waktu yang bersamaan.

Metode grounded (grounded research) bertujuan unutk mengetahui proses pengarsipan yang dilakukan selama ini. Dengan metode ini diharapkan dapat mengetahui perbandingan antara data/ fakta di lapangan dengan teori-teori yang ada terhadap proses yang ada sehingga mempermudah peneliti dalam membuat rencangan sistem pengarsipan bagi perusahaan.

\section{Metode Pengumpulan Data}

1. Observasi

Pengumpulan data dilakukan dengan cara pengamatan langsung di tempat penelitian, yaitu pada PT Kartika Graha Indonesia. Peneliti mengamati secara langsung bagaimana proses inventory barang yang sedang berjalan sekaligus mengumpulkan data serta keterangan-keterangan yang akan digunakan dalam penelitian.

2. Wawancara

Penelitian ini juga menggunakan metode wawancara langsung dengan General Manager perusahaan PT Kartika Graha Indonesia, yaitu Bapak Amik Budiyanto untuk mengetahui sistem inventory barang yang sedang berjalan serta kendala-kendala yang menghambat dalam proses 
inventory barang tersebut. Selain itu, wawancara juga dilakukan kepada beberapa karyawan yang ada. Dengan melakukan wawancara, informasi mengenai proses inventory barang pada PT Kartika Graha Indonesia dapat diketahui secara detail sehingga mendukung kebutuhan sistem.

3. Studi Kepustakaan

Metode pengumpulan data dengan studi kepustakaan dilakukan dengan mengumpulkan data dan informasi dari kutipan-kutipan buku-buku, serta beberapa hasil penelitian bahan lainnya yang berkaitan.

\section{HASIL DAN PEMBAHASAN}

Aturan sistem yang diusulkan PT Kartika Graha Indonesia pada perancangan inventory barang adalah sebagai berikut:

a. Staf admin gudang meng-input data barang dan supplier.

b. Admin gudang harus mengecek data barang yang ada di sistem untuk di lihat barang apa yang harus dipesan.

c. Barang yang dikirim oleh supplier didata dan disimpan datanya di penerimaan barang.

d. Admin gudang memvalidasi barang yang diinginkan sub konraktor dan meng-input data barang yang akan keluar.

e. General Manager menerima laporan data stok barang, laporan pemesanan, data barang keluar, dan data barang masuk.

Berikut ini merupakan penggambaran tentang sistem yang diusulkan pada perancangan inventory barang pada PT Kartika Graha Indonesia secara keseluruhan dalam bentuk diagram konteks.

\section{Diagram Konteks Sistem yang Diusulkan}

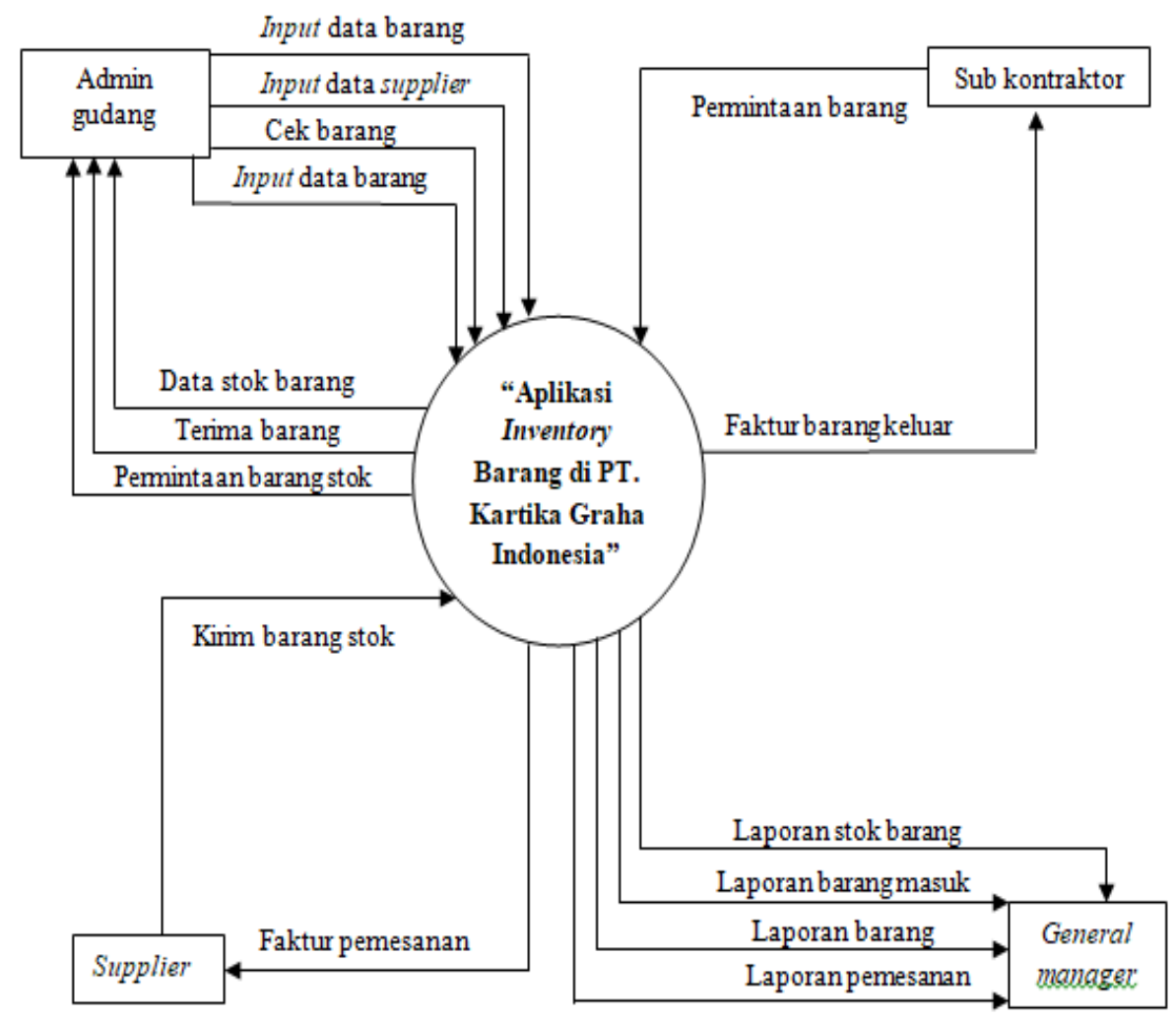

Gambar 1. Diagram Konteks Sistem yang Diusulkan 


\section{Entity Relationship Diagram (ERD)}

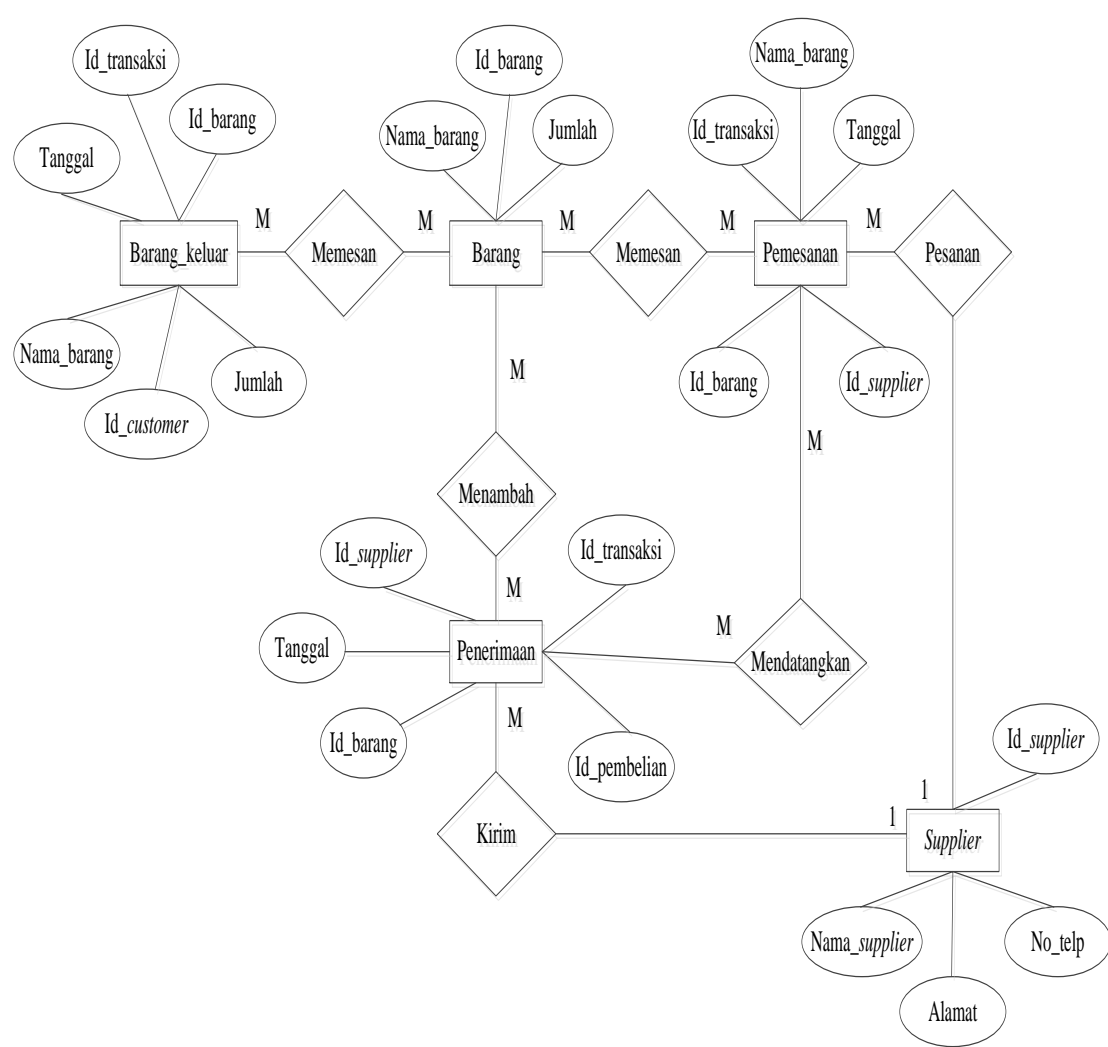

Gambar 2. Entity Relationship Diagram (ERD)

\section{Rancangan Tampilan Layar}

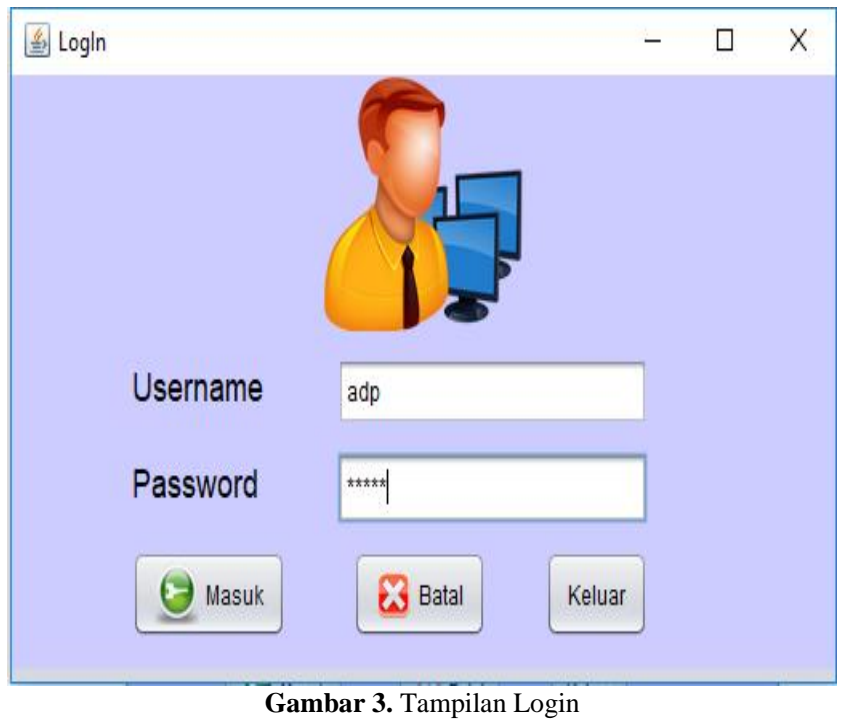

Tampilan login adalah tampilan keamanan sistem di mana pengguna yang tidak memiliki akses tidak dapat menggunakan sistem tersebut. Yang dapat menjalankan sistem hanyalah orang yang memiliki akses penuh terhadap sistem inventory barang. 


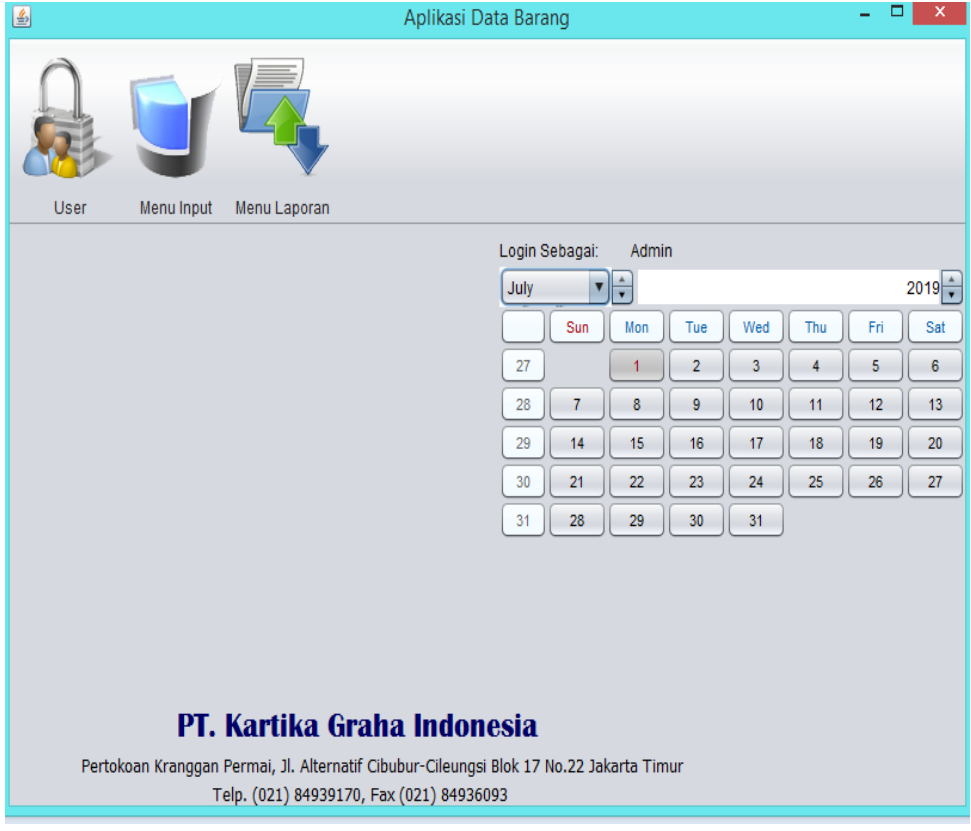

Gambar 4. Tampilan Menu Utama

Tampilan menu utama adalah tampilan dasar program sistem inventory barang yang di mana sebagai bagian penunjang untuk mengakses menu-menu lainnya. Pada tampilan menu utama terdapat Menu User, Menu Input dan Menu Laporan.

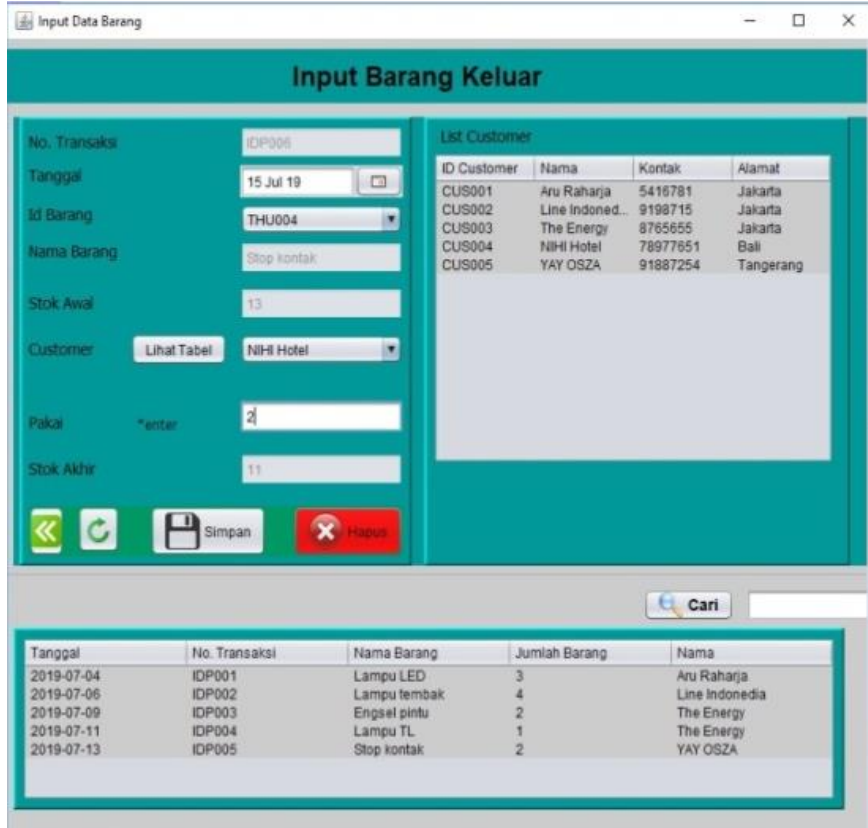

Gambar 5. Tampilan Data Barang Keluar

Tampilan data barang keluar digunakan untuk melakukan pendataan barang yang ingin dikeluarkan dari tempat penyimpanan dan juga untuk data barang yang ada pada database barang secara otomatis, data barang keluar sudah otomatis dapat menghitung stok barang yang ada. 


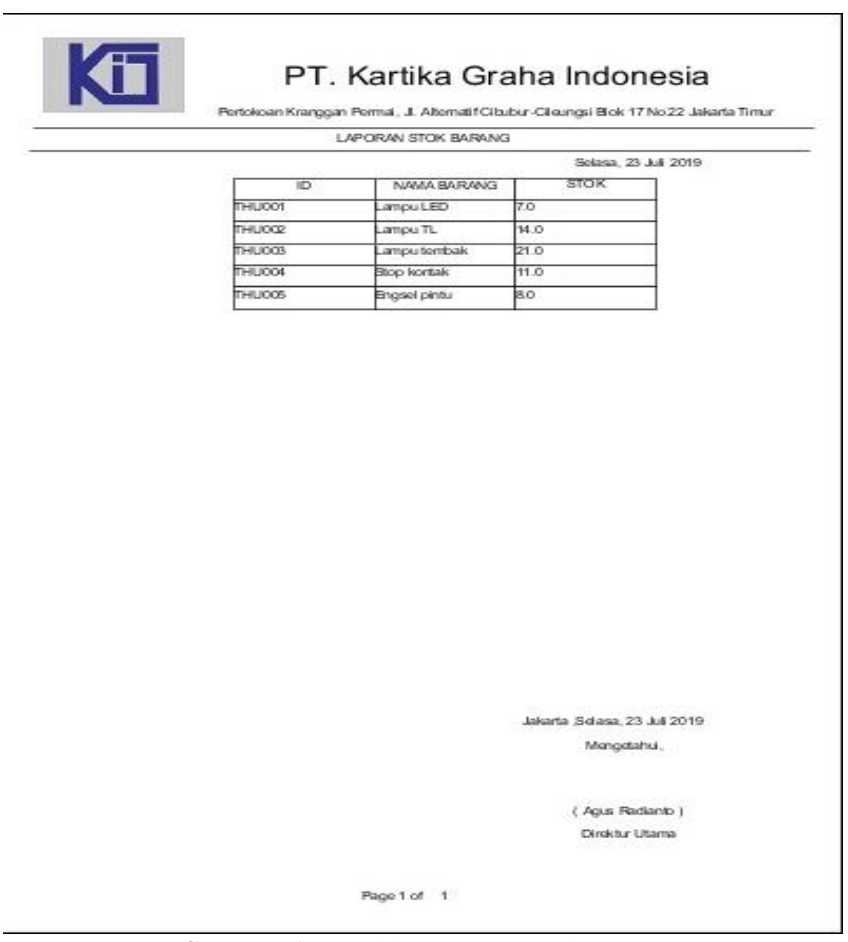

Gambar 6. Tampilan Laporan Stok Barang

Tampilan laporan stok barang ini di buat untuk laporan yang dapat dilihat oleh general manager sebagai bahan penilaian dan arsip perusahaan setiap bulan.

\section{SIMPULAN}

Adapun, kesimpulan yang diperoleh dari pembuatan aplikasi inventory barang pada PT Kartika Graha Indonesia, adalah sebagai berikut:

1. Pengelolahan data inventory barang sudah terkomputerisasi.

2. Dengan aplikasi ini maka keakurtan data inventory barang lebih optimal.

3. Dengan adanya aplikasi ini, maka penyimpanan data barang di PT Kartika Graha Indonesia jauh lebih baik dan tidak membutuhkan waktu yang lama dalam melakukan pencarian data.

Dengan diterapkan aplikasi inventory barang pada PT Kartika Graha Indonesia ini merupakan salah satu langkah maju dalam penerapan teknologi informasi. Aplikasi inventory barang yang di buat hanya sebagai penunjang proses inventory barang untuk mengefisienkan waktu dan keamanan data yang setidaknya dapat membantu bagian admin gudang di dalam kontrol barang kepada PT Kartika Graha Indonesia.

\section{DAFTAR PUSTAKA}

Hasanudin, M. (2018). Rancang Dan Bangun Sistem Informasi Inventori Barang Berbasis Web ( Studi Kasus Pt . Nusantara Sejahtera Raya ). Jurnal IKRA-ITH Informatika, 2(3), 24-37.

Ladjamudin, A.-B. (2015). Data Flow Diagram. Graha Ilmu.

Miftahul, H. (2010). Aplikasi inventory multi store plus management dengan java. Elex Media Komputrindo.

Sugiyono. (2014). Metode Penelitian Pendidikan Pendekatan Kuantitatif, Kualitatif, dan R\&D. Bandung: Alfabeta

Syarif, I., \& Mustagfirin. (2018). Sistem Informasi Inventory Barang Pada Apotek Sultan Menggunakan Metode FIFO. Jurnal Ilmiah Cendekia Eksakta, 119-125. 